\title{
人の精密な手指機能を再建する 五指型筋電義手*
}

Five-fingered Myoelectric Hand for Realizing a Precise Human-hand Function

\section{加藤 龍** 横井浩史**}

Ryu KATO and Hiroshi YOKOI

\section{1. はじめに}

人の手指は, 知的活動のほとんどを具現化し, 日常生活 を支える最も重要な器官である，その手指のはたらきは， さまざまな形・大きさの物体に適合し，しっかりと把持す るだけでなく, 道具を掴み, 腕と一体化させることで, 手 指だけで到達し得ないさまざまな機能までも実現する。ま た, 指先には圧覚, 温覚, 痛覚などの纎細なセンサを具備 し, 把持している実感や安心感を得ながら複雑かつ精密な 作業を達成している.

切断などの事故や先天性欠損などで失ったこれら手指機 能を人工的に創りだすことは, 現代の科学技術をもってし ても容易ではない，精密工学では, この課題について 1970 年代から先進的に取り組み, 中でも舟久保（東京大 学 $)^{1)}$ や加藤 (早稲田大学 $)^{2)}$ らの筋電義手 (筋活動電位を 用いて制御される電動義手) 研究は多くの成果を上げ, 筋 電義手の研究基盤を築いたことは世界的に知られている. 近年の筋電義手研究では, 精密工学をはじめとし, ロボッ 卜工学, 情報工学, 脳神経科学などさまざまな学術領域で 培った先端技術を融合し，人の精密な手指運動を具現化す る次世代の五指型筋電義手を創りだす試みが数多く行われ ている.

本解説では, 五指型筋電義手に関わる基礎的な技術から 最先端技術そしてその未来について筆者らの研究グループ の筋電義手事例を交えながら概説する.

\section{2. 五指型筋電義手に関する最新研究動向}

筋電義手とは，筋収縮時に発生し皮膚表面で計測される 表面筋電位を用いてロボットハンドを制御する電動義手で ある。その概要を図 1 に示す，手指欠損者は，ロボット ハンドが搭載されたソケット（補装具）を断端部に装着 し，義手として操作する．ソケット内側には，前腕筋群の 筋活動が計測される体表位置に触れるよう筋電センサが設

*原稿受付 平成 25 年 12 月 24 日

*正会員 電気通信大学大学院情報理工学研究科知能機械工学専攻 (東京 都調布市調布ケ丘 1-5-1)
置されており，計測された信号から筋電制御部で操作者の 動作意図を識別し，識別された動作となるようロボットハ ンドが制御される。また，人の手の見た目を模した装飾グ ローブをロボットハンドに被せることで違和感のない日常 生活上での利用を可能にしている.

手指切断者が希望する人の精密な手指機能を有する義手 を実現するには，(1）ロボットハンドの機械設計/制御, （2）筋電を用いた動作意図識別（情報処理），（3）義手に 触覚を付与するための触覚フィードバックといった機能 を，人に適合した形で具現化しなければならない．

義手の性能設計は, 従来のロボットハンドと対比する と，位置と姿勢の正確性よりも，しっかりと物を握らなけ ればならないことや人が可搬できる重量や大きさに納めな ければならないなどその制約は大きく, 関節位置の制御性 能よりも，把持力性能や軽量化が何よりも優先される.

また，目と手は強く連動して扔り，生体信号に基づいた 制御系を用いて直感的な操作を可能とすることにより，人 の適応能力を生かした機械と人の共同作業が可能となる. しかしながら, 生体信号は個人差や時変性が大きく, ここ に機械学習などの適応機能を利用する必要がある.

一方，鎌倉ら ${ }^{3}$ によれば，手指の基本機能は 8 種類のク ラスに分類され，把持機能 5 種類, センシング機能 2 種 類, 操作機能に大きく分けられる (図 2). 特に把持機能 に関しては，さまざまな物体形状に適合するような握り方 が必要であり, 多様な力点による物体への力伝達により, 物体と腕を一体化する機能を達成している。このような把 持機能は五指と掌の運動自由度により実現されているた め, まず義手の指部の機構と制御の両方の技術が必要と なる，そこで，2.1節で 5 指型ロボットハンド， 2.2 節で表 面筋電位を用いた手指動作の識別に基づく義手制御法に関 する最新研究動向について概説する。

さらに, 義手に触覚機能を具備することは, 義手操作者 が把持物体の形状を視覚に頼らず把握することを可能にさ せ，違和感のない自然な物体把持とその安定性の向上につ ながる。 また同時に，義手を人の手の性状（見た目や柔ら かさ）に近づけることができれば，手指欠損者の社会活動 


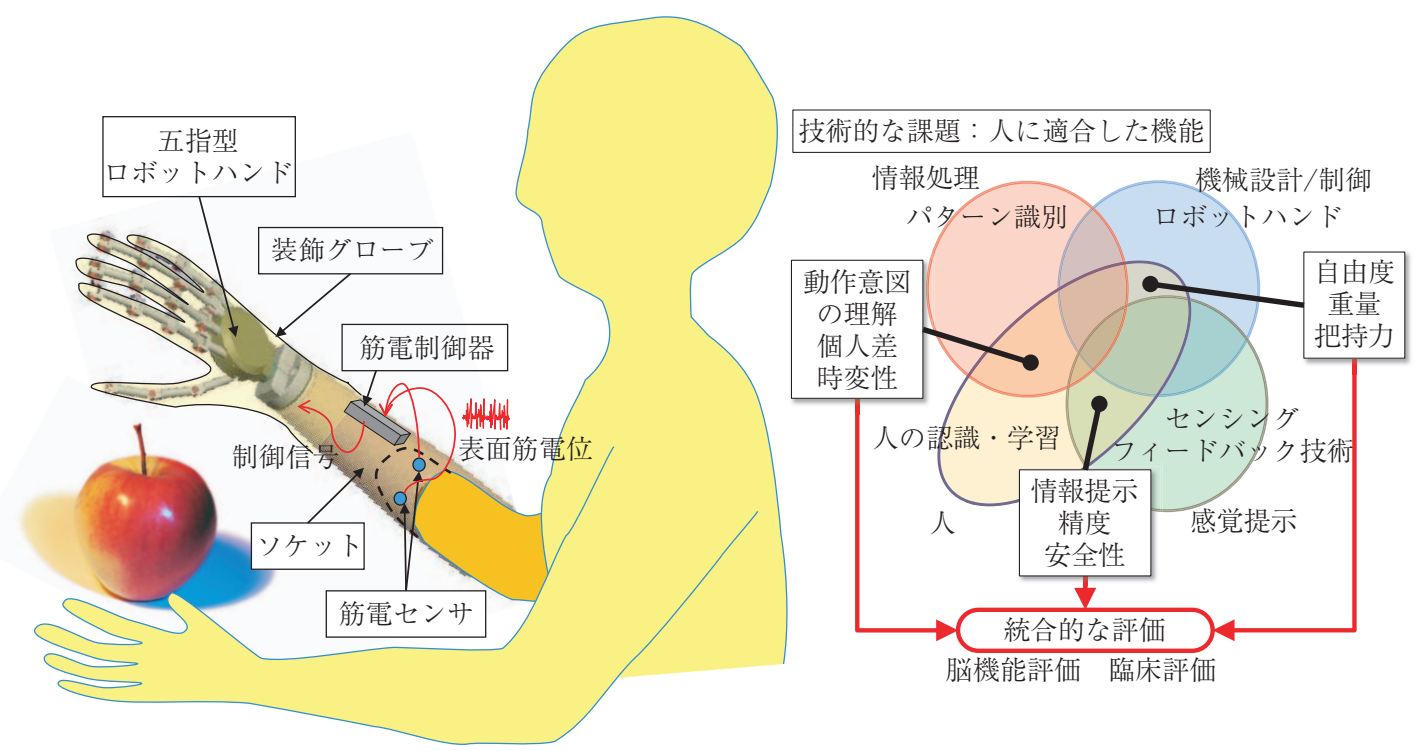

図 1 筋電義手の概要と技術的な課題

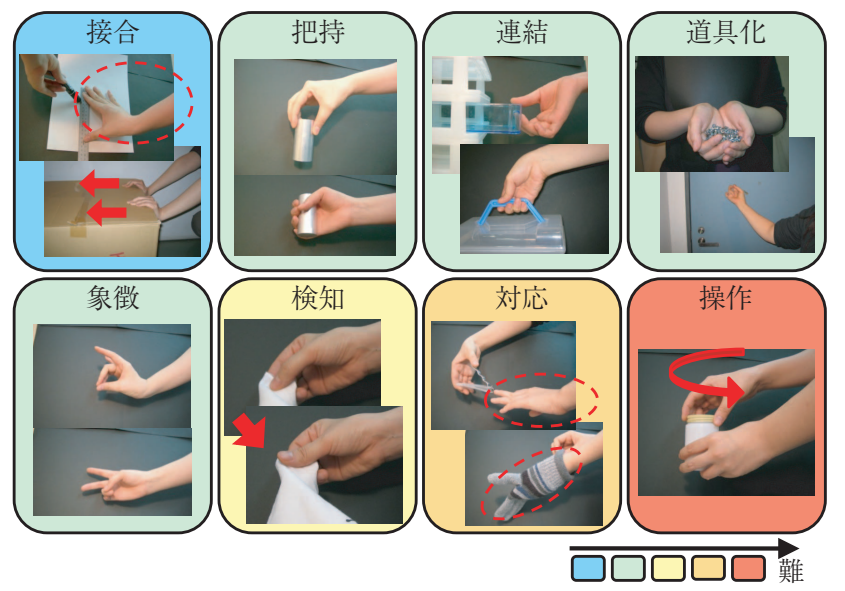

図 2 鎌倉らによる手指機能の分類

を促し，QOL（生活の質）を向上させる。2.3 節では，触 覚フィードバック及び装飾グローブについての動向も概説 する.

\section{1 五指型ロボットハンド}

義手研究は, ロボットハンドの応用の一つの代表例であ り、ここ 10 年で非常に大きく進歩した研究領域である. 世界的にも盛んに研究開発が行われており，毎年のように 新しいタイプのロボットハンドと義手としての応用事例が 報告されている。最近では，1）i-limb（Touch Bionics 社), 2) Bionic Arm（シカゴ・リハビリテーション研究 所), 3) DEKA Arm (DEKA Research and Development Corporation 社）が特筆すべき成果をあげている.

i-limb ${ }^{4}$ は油圧駆動の超小型五指ハンドであり, 開閉速 度は比較的ゆっくりである（開閉に要する時間は 1 秒間程 度）が，このサイズで五指の独立動作を実現させた例は珍 しく，拇指と示指での側面把握（Lateral pinch）を用いた 名刺などの把持，拇指と示指での対立摘み，三面対立握り

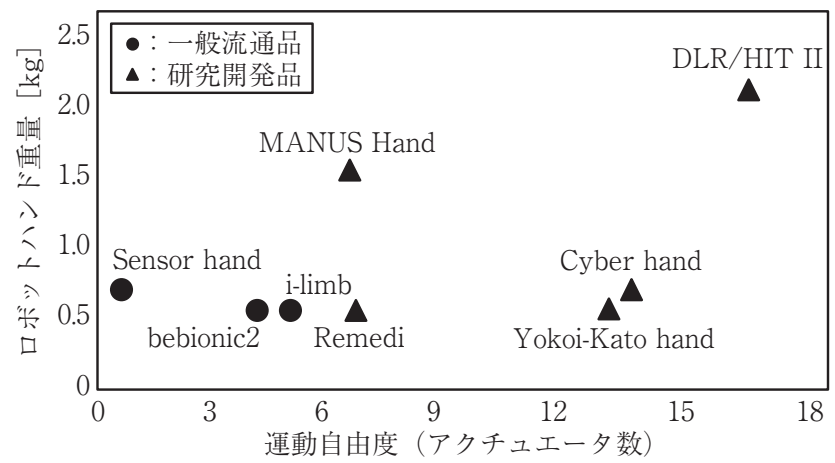

図 3 五指型筋電義手の研究動向

によるボールペンの把持など複雑な精密握りを実現すると ともに，四指を用いたひっかけ握り，球面把持， 円筒把持 など，握力握りにも対応できている.

また, Bionic $\mathrm{Arm}^{5)}$ はともに電動モー夕による駆動方式 をとるが，肩関節 3 自由度，肘関節 1 自由度，手指開閉 1 自由度の制御を筋電位から実現したアームである。特徵 は，大胸筋へ手指の神経を移植することにより，指先の筋 電を胸部で取得できるようにしたことで，筋電を用いたア ームと手指開閉の制御を実現したところにある.

DEKA $\mathrm{Arm}^{6)}$ では, 手先の運動自由度を向上させてお り, 五指の独立動作を実現している。このアームの特徵 は, 制御信号を筋電だけではなく, 足底に圧力センサを設 置し，ウエイトシフトによりアームや手指を制御するハイ ブリッド方式を採用していることである。これにより，握 り方や摘み方を変え細かい作業を実現している。

これらの義手はその機能性を向上するために搭載するア クチユエー夕数を増やしているが, それに比例する形で重 量が増加する。研究開発は, 軽量・多自由度の方向へ進み つつあり，五指独立動作の実現を模索した取り組みも散見 される $(\text { 図 3 })^{7) \sim 12) . ~}$ 


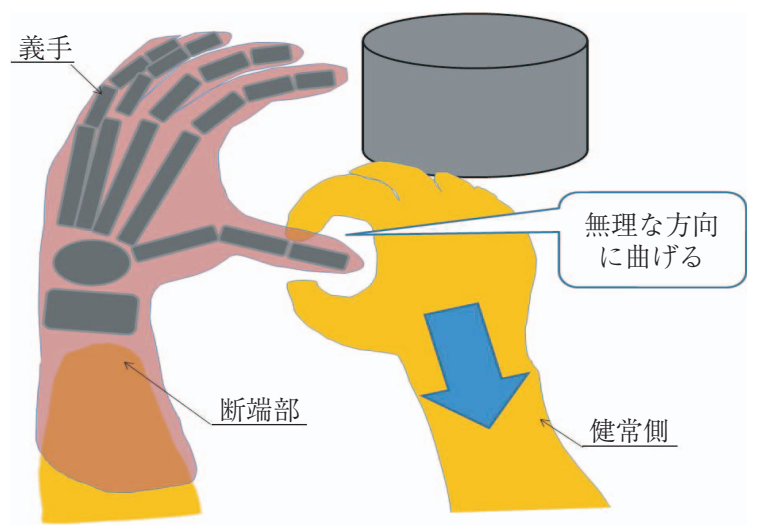

図 4 無理な方向へ指を曲げる

その一方で，義手とロボットハンドは，似て非なるもの であることを忘れてはならない. 企業のデモや大学の研究 室で使われるロボットハンドは，手の形を模したものがほ とんどであり，重量やサイズの制限は特に設定されていな い.また，日常生活環境での使用を想定していないため に，体重を支えたり，無理な方向に曲げられたりといっ た，われわれが普通に行う手指の運動を想定する必要がな い，取り扱い者は，技術者や専門家に限られる。

しかし，義手の利用者のほとんどは，非専門家であり， 時には未成年者（乳児を含む）である。もち万ん，ロボッ トの脆弱さなどは，想定していないために，指先で体重を 支える場合や，大きなものをつかもうとして手指に無理な 力をかけて，広げようとすることが頻繁に起こる（図 4). このような状況に扔いて，義手が使えなくなってしまうよ うでは, 利便性が大きく損なわれるために, 従来は, 分厚 い金属の骨組みによって頑丈な手指と掌が構成されてい た，従来の義手が，不自然な硬さと重量感をもっているの は,このためである.

これらの問題に対して，筆者らの研究グループでは，さ まざまな形状に対する物体の把持を達成するために，手指 の形状と動力系を模倣したハンドを設計し, 片側滑り軸受 け関節構造とした（図 5 $)^{12)}$ 。骨格は，20 関節 24 自由度り ンク構造とし，手根骨リンクは，特に区別することなくま とめて一つのリンクとして構成した。関節の駆動機構は, ワイヤー毫引式を採用することにより，モータをハンド部 から独立させ, 義手先端部の重量軽減を図った。能動関節 は，DIP 関節，PIP 関節，MP 関節，親指 CM 関節，手首 関節であり, 親指以外の CM 関節は受動関節である。掌 内の中手骨リンクは，バネ要素により左右のリンクを相互 に締結することにより，手指を開いたときに，中手骨リン クが放射状になり，掌が最も広がるような姿勢を維持する 機能を有する.

これらの機構を用いて, 右手手根関節離断の 60 代女性 切断者用に開発し, 5 指 18 関節 13 自由度 (手首部 2 自由 度), 触圧に対する感覚フィードバック機能を搭載した。 総重量は, $1.2 \mathrm{~kg}$, 把持力 $55 \mathrm{~N}$, 関節角度分解能 $1 \mathrm{deg}$., 開閉速度 $200 \mathrm{~ms}$ を実現している。ささらに，2つの指節を

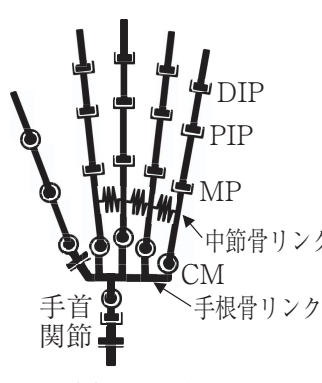

（a）運動自由度

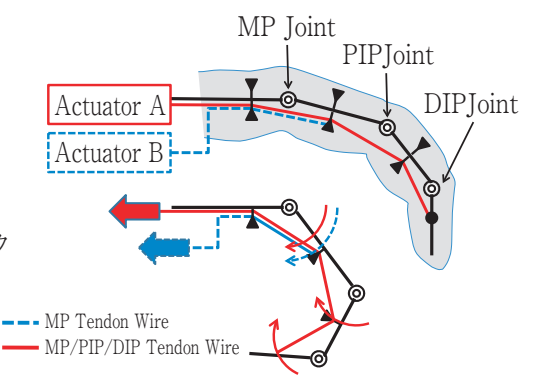

（b）干渉駆動型ワイヤ毫引メカニズム

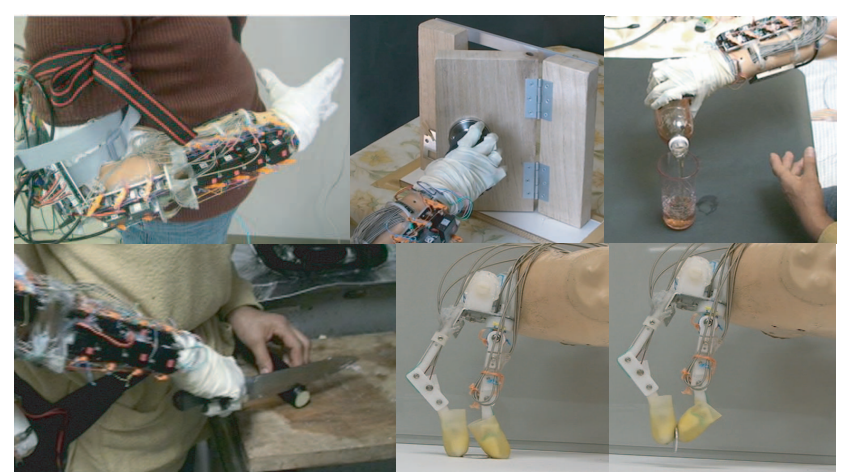

(c) 日常生活動作の実現

図 5 人の手指の形状と動力系を模倣した五指型ロボットハンド

バネ力で連結し, 滑るように嵌合された片側すべり軸受で 指関節を構成し, 指が無理な方向に曲げられて過大な力が かかると関節が脱臼し, 連結バネ力と屈伸ワイヤーの㐮引 力で関節が自動復帰するロバストなロボットハンドの開発 を行っている(図6).

\section{2 表面筋電位を用いた手指動作の識別}

表面筋電位は, 筋線維から発生する活動電位を皮虐表面 で捉えたものである。手指動作を支配する複数筋の個々の 筋活動を筋電位から特定できれば, 複雑な手指動作の識別 は可能であると考えられるが, 表面筋電位は, 皮膚表面上 で計測することから, 複数の筋群の活動電位が重畳された 複雑な信号となり, その特定が難しい。 また, 表面筋電位 から得られる信号特徴は, 個人ごとに筋脂肪量が異なるこ とから個人差が大きく, 発汗や筋疲労などにより時変性も 有する，さらに，人の手指動作を支配する筋群は，そのほ とんどが手掌部あるいは前腕部に内在するが, 筋電義手を 使用する手指欠損者の欠損の程度により残存する筋群は個 人よってまちまちである.

そこで, 表面筋電の信号特徵と五指型筋電義手に行わせ る手指動作パターンとの対応関倸を機械学習により後天的 に獲得し, 獲得された識別関数を用いて, 表面筋電から手 指動作を識別するパターン認識問題に帰着させる手法によ り，5 指型筋電義手を制御する研究が多い（図 7)

手指動作の識別に用いられる表面筋電の信号特徴として は, 全波整流值の区間平均（積分筋電位）などの時間ドメ イン特徴量や, パワースペクトルや zero-crossing など周 波数ドメイン特徵量が用いられる。

前者は, 筋活動量と信号振幅強度に高い相関性（最大随 


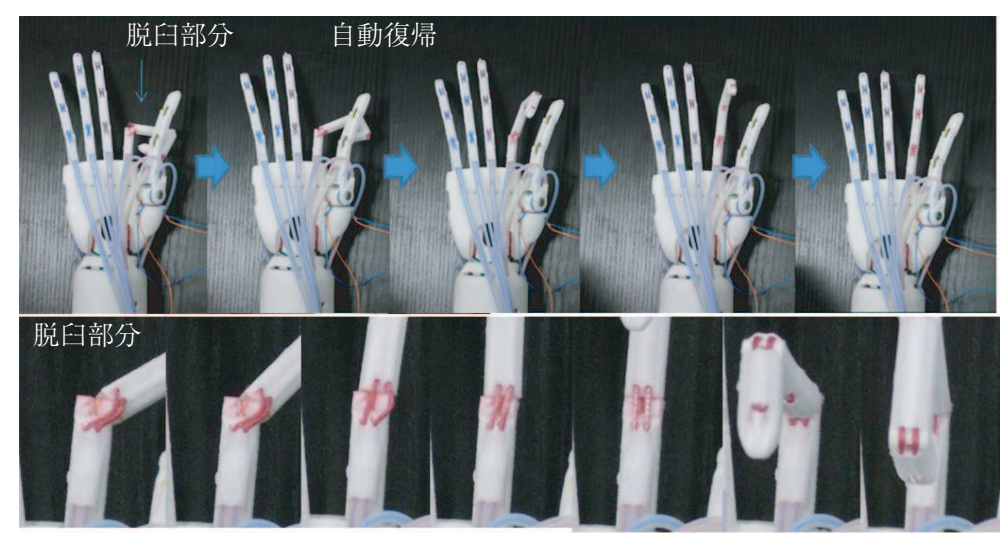

図 6 片側すべり軸受けを用いた自動復帰型脱臼関節

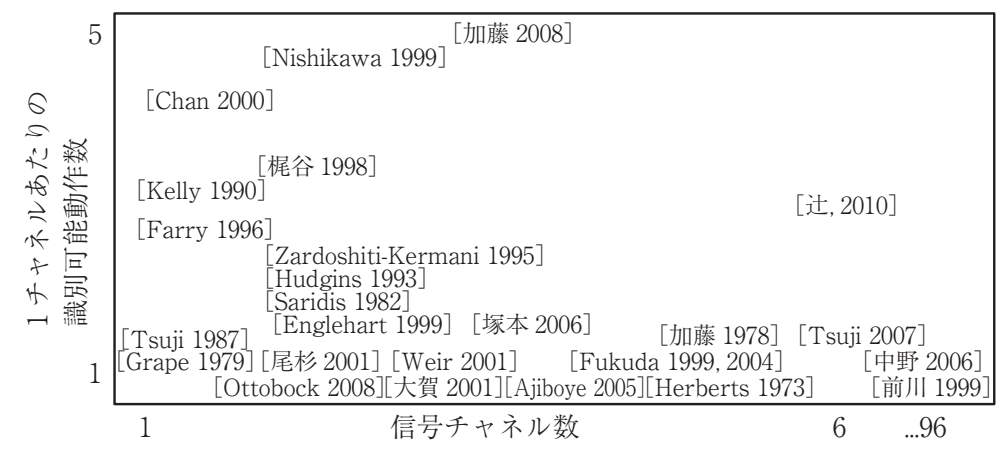

図 7 表面筋電を用いた動作識別の研究動向

意収縮力の 10～80\%の筋収縮力で高い線形性）が見られ ること, また後者は, 表面より深いところに存在する筋群 の活動ほど，筋電の高周波成分が減衰して表面で計測され たり，筋疲労により除波化されるなど周波数成分に手指動 作を識別する情報量が含まれることに起因する。

一方，識別関数の設計においては，70〜80 年代には, 閯值処理や AR モデルなど線形モデルによる識別が主流で あり手指 6 動作程度の識別が可能であった. 90 年代に入 るとニューラルネットワークやFuzzy の登場により非線 形関数による識別手法が考案され, 手指 8 動作程度の識別 が可能となった。 2000 年代には, サポートベクターマシ ンを用いる高精度な識別関数や隠れマルコフモデルやオン ライン学習系が内包される識別関数など時変性を考慮した 識別関数の設計が行われている.

また, 対象とする手指動作数の増加に伴い膨大な学習サ ンプル数や学習時間が必要となり, 起こりうる全ての手指 動作に対応した筋電信号を計測することは非常に難しいこ とから, ここ数年, 表面筋電位から筋シナジー（動作単 位）を推定し, 複数の筋シナジーの組み合わせによって複 雑な手指動作を表現する試みが行われ, 辻らの研究では, 前腕 6 箇所の表面筋電から手指 18 動作の識別に成功して いる ${ }^{13)}$.

表面筋電位から手指動作を識別する研究は, 筋電義手に 限らず，筋電インターフェースとして可能性を秘めてい
る. 一般に, 表面筋電位の筋電計測箇所 (センサー数) す なわち, 空間解像度を高くするほど, 手指動作の識別動作 数は多くなる傾向がある. しかし, 筋電義手特有の問題と して，断端部によって計測できる皮膚表面積が小さい，多 くの電極を配置すると配線数が多く肥大化し，電極と皮膚 との接触状態が悪化するなど, 多電極化しづらい.

そこで，筆者らのグループでは 3 個の筋電センサで計測 される筋電信号（信号特徴としては, 積分筋電位とパワー スペクトル) から前腕 14 パターン（手首 6 動作, 5 指開 閉, 母指の屈伸, 薬指一小指の屈曲, 3 指つまみ/ひらき, 安静）の手指動作をニューラルネットワークにより長期安 定的に識別可能となるオンライン学習型動作識別手法の提 案を行っている $\left(\right.$ 図 8 ${ }^{12}$. 詳細は割愛するが, 識別関数 パラメータを決定する各動作の学習サンプルを保持し, 識 別結果と信号特徵の時系列を監視しながら, 情報エントロ ピー指標によりクラス競合度合いを制御しながら学習サン プルを自動追加・削除して識別関数パラメータを逐次的に 修正するオンライン学習を導入している.

\section{3 触覚フィードバックと装飾グローブ}

触覚フィードバック技術は, 主にバーチャルリアリティ VRの研究領域においてその発展を遂げてきた。筋電義手 においても, 研究レベルでは, 指先や掌に搭載された圧力 センサ情報に基づいて振動刺激で触覚をフィードバックす る研究 ${ }^{14)}$ や, 正中神経に電極アレイを埋め込み, ロボット 


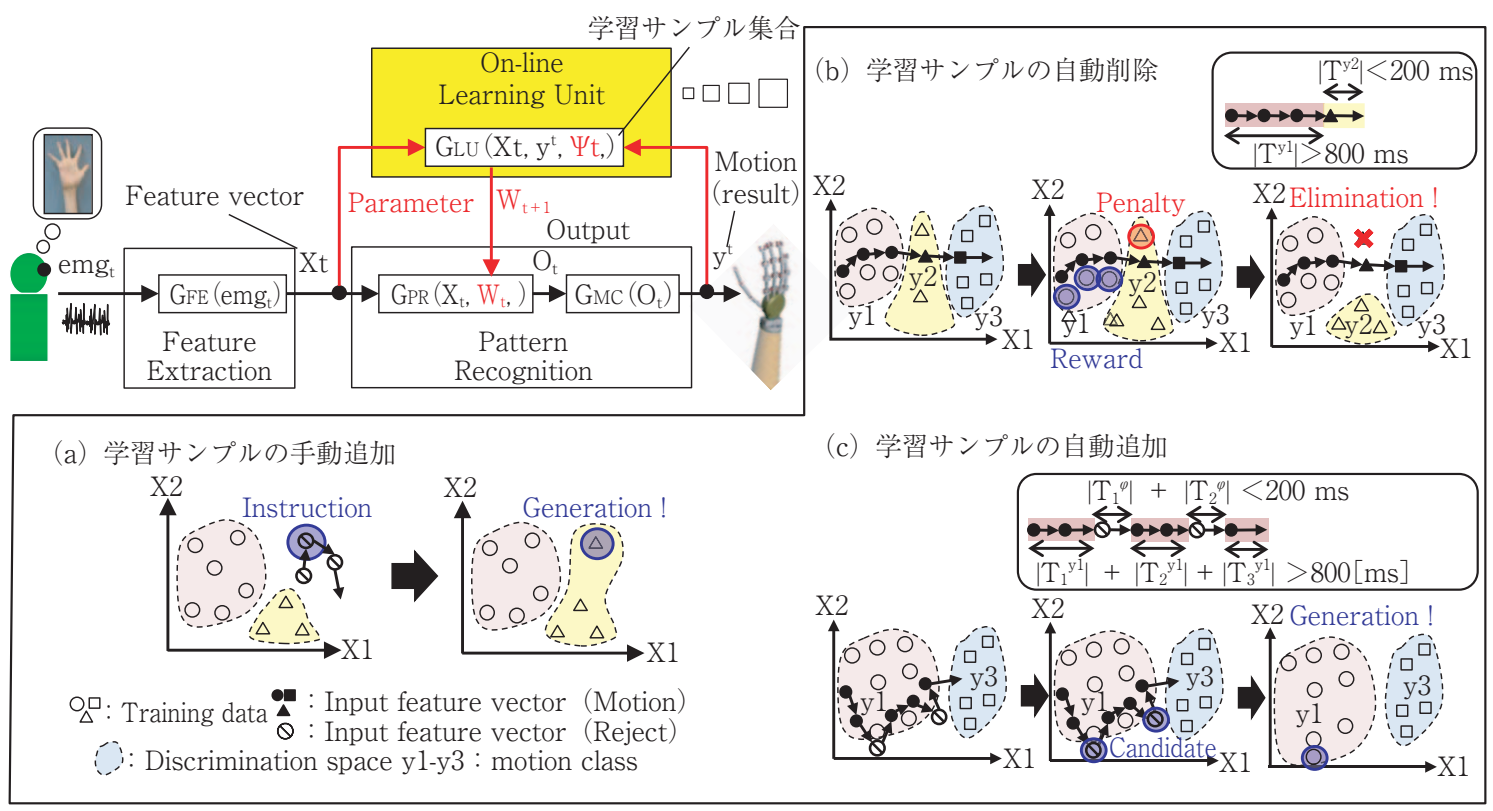

図 8 オンライン学習型動作識別手法

ハンドの触圧を直接侵襲的に提示する神経インターフェー スの研究 ${ }^{15)}$ ，また筆者らの研究グループにおいても，表面 電気刺激による錯覚を利用した非侵襲型触覚提示システム 等が提案されている ${ }^{16)}$. また現在市販されている筋電義手 においては触覚を有するものはごくわずかである。

人の指先は非常に鋭敏な触覚を有し（指の指先の 2 点弁 別閾 $1.6 \mathrm{~mm}$ 程度), 多くの感覚受容器をもつ. これを工 学的に実現するには，高い空間密度で触圧センサを小さい 指先に配置しかつ刺激素子を断端部に配置しなければなら ない. しかし，多電極化・多素子化は同時に多配線化につ ながるうえ, 筋電義手の使用環境を考えると断線などの故 障しない工夫が必要となり, 現状では人と同程度の触覚フ イードバックを行うことは大変困難であり, 今後の研究発 展に期待される。

一方，義手ロボットハンドが人の手の外観を有すること は，日常生活を送る上で極めて重要である。市販されてい る筋電義手では, 塩化ビニルで構成された人の手を模した 装飾グローブが主流である。しかし，塩化ビニル製のグロ ーブは非常に固く，ロボットハンドの動きを阻害するため 動力ロスが大きいという問題がある。石黒らが開発したジ エミノイド ${ }^{17)}$ をはじめとする「実在人間型ロボット」の研 究分野では，シリコンゴムを用いて人のやわらかい皮膚性 状を表現するアプローチがあるが, 一般にシリコンゴムで は引裂強度が低く, 耐久性がよくない。 そこで筆者らの研 究グループでは, 現在エラストマーゲルを用いた低硬度 （硬度 JIS-E5～50）で高い伸び率（1300\%）を実現する装 飾グローブの開発に着手している（図 9）。樹脂製金型を 用いて多層構造で整形する手法を考案しており, 手指部位 ごとに皮膚厚みを変更することや爪など異質素材のインサ ートを可能とする一体成型手法の開発を目指したい。

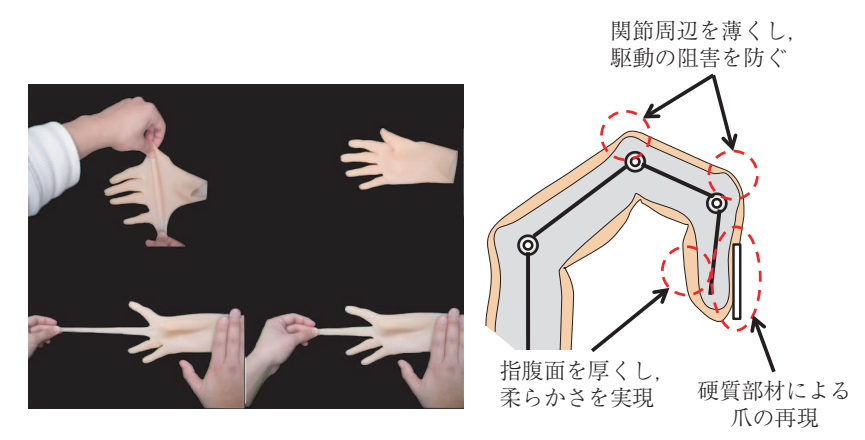

図 9 エラストマーゲルを用いた装飾グローブ

\section{3. おわりに}

これまで，五指型筋電義手の最新技術について概説して きた。ここ数年で $3 \mathrm{D}$ プリンター技術の急速な発展と低価 格化により，これまで専門的加工技術を要し，かつ「金食 い虫」であったロボット研究を始めるハードルが低くなっ たことで多くの研究者が容易にロボット開発環境を手に入 れることが可能となり, 多くの素晴らしいロボットが提案 されている。

筋電義手研究でも例外ではない, 現在の筋電義手は, 使 用者に合わせてオーダーメイドで製作されるうえ, その市 場規模は小さく，比較的高価なものであった。 それに対し て, 筆者ら研究グループでもナイロン粉末を焼結させ積層 する粉体成形法による義手ロボットハンド設計を行ってお り，人の筋骨格を模した指関節の設計や低価格へのアプロ ーチを始めていたが，ロボットハンドの設計データのオー

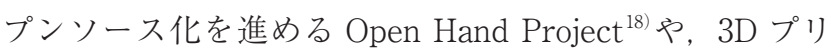
ンターで造形したロボットハンドをスマートフォンで筋電 制御する筋電義手 Handie など, 研究者だけでなく一般の 方でもこのような取り組みが行われるようになってきた. 
耐久性や造形精度などまだまだ課題は多いが，今後急速に 新しいロボットハンド機構の提案が行われ, 人の精密な手 指機能を実現できるものが出てくると確信している.

また，制御においても表面筋電位だけでなく，直接脳活 動からロボットハンドを制御する Brain Machine Interface 技術も急速に発展を遂げている。特に，脳組織に針電極を 刺入する夕イプに比べ侵襲性が低く頭蓋内の脳表面に留置 された電極から計測される皮質脳波を用いた BMIに注目 が集まっており，柳澤らの研究 ${ }^{19)}$ では，簡単なロボットハ ンドの制御にも成功している。今後は簡便に脳活動計測が 可能となる技術とセットで, 新しい neuro-prosthesis が 登場するに違いない。

子供のころ，テレビの前で $\mathrm{SF}$ やアニメの中で主人公が 怪我した手の代わりにロボットハンドを装着して活躍する 姿に魅了され，そのような手の実現を夢見ていたが，そん な夢が現実になるのは遠い未来ではなくなってきたことを 実感している。

\section{参 考 文 献}

1）舟久保熙康, 立川透, 橋本福雄, 山口隆男, 斎藤之男, 山内裕 雄, 河村洋: 電動式作業用義手の設計・試作に関する研究, バ イオメカニズム, 2 (1973) 134-143.

2) 加藤一郎, 小泉裕之, 浅羽樹一郎, 坂田和俊: 多自由度義手の 制御信号と位置フィードバック (1 部 感覚と筋), バイオメカ ニズム, 4 (1978) 35-41.

3）鎌倉矩子：手のかたち手のうごき，医㐘薬出版，（1989）.

4) http://www.touchbionics.com/

5) http://www.ric.org/research/centers/bionic-medicine/

6) http://www.dekaresearch.com/deka_arm.shtml

7) M.C. Carrozza, G. Cappiello, S. Micera, B.B. Edin, L. Beccai and C. Cipriani : Design of a Cybernetic Hand for Perception and Action, Biol. Cybern., 95 (2006) 629-644.

8) S.A. Dalley, T.E. Wiste, T.J. Withrow and M. Goldfarb : Design of a Multifunctional Anthropomorphic Prosthetic Hand with Extrinsic Actuation, IEEE/ASME Transations on Mechatronics, (2009).

9) J.L. Pons, E. Rocon, R. Ceres, D. Reynaerts, B. Saro, S. Levin and W. Van Moorleghem: The MANUS-HAND Dextrous Robotics Upper Limb Prosthesis: Mechanical and Manipulation Aspects, Autonomous Robots, 16 (2004) 143-163.
10) H. Huang, L. Jiang, Y. Liu, L. Hou, H. Cai and H. Liu: The Mechanical Design and Experiments of HIT/DLR Prosthetic Hand, Proceedings of the IEEE International Conference on Robotics and Biomimetics, (2006).

11) http://rslsteeper.com/

12）加藤龍, 横井浩史 : 適応機能を有する運動意図推定システム一 高機能ロボットハンドと日常生活支援, 人工知能学会論文誌, 23, 3 (2008) 326-333.

13）辻敏夫, 島圭介, 村上洋介：筋シナジーに基づく複合動作のパ ターン識別, 日本ロボット学会誌，28, 5 （2010）606-613.

14）奥野竜平, 吉田正樹, 内山孝憲, 赤澤堅造 : 可聴周波数以下の 皮膚振動刺激を用いた義手感覚フィードバック装置, 電子情報 通信学会技術研究報告. MBE，ME とバイオサイバネテイック ス, 96, 581 (1997) 99-106.

15）鈴木隆文, 國本雅也, 満㴊邦彦: 感覚神経刺激による人工触圧 覚生成, BME, 18, 4 (2004) 29-35.

16) T. Hirata, T. Nakamura, R. Kato, S. Morishita and H. Yokoi: Development of Mobile Controller for EMG Prosthetic Hand with Tactile Feedback, Proc. of IEEE/ASME International Conference on Advanced Intelligent Mechatronics, MA4.2 (2011).

17) http://www.irc.atr.jp/research_project-2/geminoid/

18) http://www.openhandproject.org/dextrus/

19) T. Yanagisawa, M. Hirata, Y. Saitoh, T. Goto, H. Kishima, R. Fukuma, H. Yokoi, Y. Kamitani and T. Yoshimine: Real-time Control of a Prosthetic Hand Using Human Electrocorticography Signals, J. Neurosurg., 114, 6 (2011) 1715-1722.

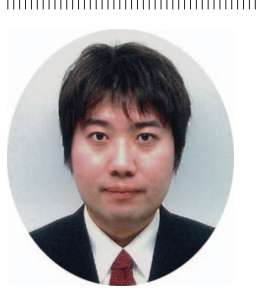
加藤 龍

2008 年東京大学大学院博士課程修了. 東京大学 特任助教を経て 2009 年より電気通信大学大学院 情報理工学研究科助教.人とロボットの融合に 関する研究に従事. 博士 (工学).

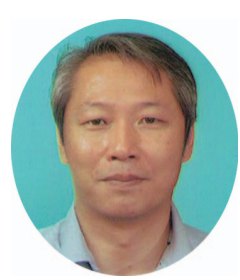

\section{横井浩史}

1993 年北海道大学大学院博士課程修了. 同年通 商産業省工業技術院研究員, 1995 年北海道大学 助教授，2004 年東京大学准教授を経て，2009 年 より電気通信大学大学院情報理工学研究科教授. 医用福祉機械，ブレインマシンインターフェー スに関する研究に従事. 博士 (工学). 